\title{
UTILIZATION EFFICIENCY OF CONSTRUCTED WETLANDS IN EFFLUENT REMOVAL AND NILE TILAPIA GROWTH UNDER DIFFERENT HYDRAULIC LOAD RATES
}

\author{
Atef M. Elsbaay ${ }^{1}$ and Hussain Sorour ${ }^{2}$
}

\begin{abstract}
The experiment was carried out at two stages. First stage, determine the optimum hydraulic loading rate and second stage, determine fish growth parameters. Wetland cell was filled with three layers of gravel, the bottom layer coarse gravel ( $\phi 30-50 \mathrm{~mm})$ with height $0.3 \mathrm{~m}$, the middle layer fine gravel $(\phi 10-20 \mathrm{~mm})$ with height $0.2 \mathrm{~m}$ and the upper layer (soil) with height $0.05 \mathrm{~m}$. Three hydraulic loading rates $(4.8,9.6$ and $19.2 \mathrm{~m}$ $\left.d a y^{-1}\right)$ were used in the present study. The data obtained were subjected to one-way analysis of variance (using SPSS program) to test the effect of the inflow and outflow nutrient concentration. The results indicated that the total ammonia nitrogen (TAN) concentration was significant variation among the hydraulic loading rates treatments and control. It was observed significantly highest in hydraulic loading rate $4.8 \mathrm{~m} \mathrm{day}^{-1}$. Total Ammonia Nitrogen concentration increased with increasing hydraulic loading rates among treatments, whereas TAN values were 0.18, 0.21 and $0.23 \mathrm{mg} \mathrm{l}^{-1}$ at hydraulic loading rates $4.8 \mathrm{~m} 9.6$ and $19.2 \mathrm{~m} \mathrm{day}^{-1}$ respectively. The results indicated that the nutrient to area loading (AL) and area retention $(A R)$ increases with increasing the hydraulic load for most of the measured nutrient parameters. The total nitrogen (TN) removal values were 7.1, 9.5 and $13.1 \%$ at hydraulic loading rates 4.8 , 9.6 and $19.2 \mathrm{~m}^{2} \mathrm{day}^{-1}$ respectively. While, the TAN was decreased with increasing the hydraulic loading rates. The theoretical dissolved oxygen consumption $\left(D O_{c o n}\right)$ were about 2.6, 4.3 and $3 \mathrm{mg} \mathrm{l}^{-1}$, representing $65 \%$, $90 \%$ and $50 \%$ of the measured DO loss throughout the wetland at hydraulic loading rate 4.8, 9.6 and $19.2 \mathrm{~m}$ day $^{-1}$ respectively. The results
\end{abstract}

\footnotetext{
${ }^{1}$ Lecturer of Agric. Eng. Dept., Faculty of Agric., Kafrelsheikh Univ., Egypt. E-mail: atef.ahmed@agr.kfs.edu.eg

${ }^{2}$ Prof. of Agric. Eng. Dept., Faculty of Agric., Kafrelsheikh Univ., Egypt.
} 
indicated that no noticeable difference between fish growth parameters observed under hydraulic loading rate for $9.6 \mathrm{~m}_{\text {day }}^{-1}$ and control treatment.

Keywords: Hydraulic loading rate, constructed wetlands, fish growth

\section{INTRODUCTION}

afr El-Sheikh governorate is considered one of the largest
governorates of Egypt for production rice crop, as well as the
production of farmed fish. Kafr El-Sheikh governorate suffers at present time from a great lack of water. In Egypt, Nile Tilapia is cultured in open or semi open systems in ponds, tanks or raceways, with a flow through of water from nearby rivers or brooks. Open aquaculture systems imply that effluents are discharged to the environment with enhanced nutrient and solid concentrations. Aquaculture effluents may have serious consequences for the environment when discharged untreated (Rennert, 1994).

Natural wetlands are an important component of marine and freshwater ecosystems. They hold and recycle nutrients, provide habitat, breeding and nursery grounds for many wildlife species and control and buffer natural foods (Hammer and Bastian, 1989). In addition, wetlands can efficiently remove organic matter, suspended solids and nutrients (nitrogen, potassium, phosphorus) through various processes including filtration, sedimentation, biological and microbiological absorption, and assimilation (Hammer and Bastian, 1989). The environmental and economical significance of wetlands has been pointed out by several authors (Sindilariu et al., 2008, 2009 and Shpigel et al., 2013).

As with all other forms of livestock farming and husbandry, aquaculture produces waste, in the form of solids (uneaten feed, faces, etc.) and dissolved material, which is transported out of the rearing system with the husbandry water. In the context of the European Water Framework Directive, aquaculture effluents are considered one point pollution sources. However, each European country is entitled to set its own rules to prevent harmful environmental effects from aquaculture effluents (Bergheim and Brinker, 2003). In Germany for instance, no common rule is applied. Here, each local authority can set own effluent standards in 
depending on the local needs. General guidelines recommend an increase between farm in and outflow of $3 \mathrm{mgl}^{-1} \mathrm{BOD}_{5}$ and $15 \mathrm{mgl}^{-1}$ total suspended solids (TSS) (Schobert et al., 2001). Also, limits for total phosphorous (TP) $\left(0.1 \mathrm{mgl}^{-1}\right)$ and total ammonia nitrogen (TAN) (1.0 $\mathrm{mgl}^{-1}$ ) have in certain cases applied (Sindilariu, 2007).

(Shpigel et al., 2013) studied the performance of constructed wetland with Salicornia persica (Chenopodiaceae) as a biofilter for effluent water drained from a semi-open recirculating mariculture system. The results demonstrated the effectiveness of $\mathrm{N}, \mathrm{P}$ and total suspended solids removal from mariculture effluent by a constructed wet land operating with this plant.

The addition of water to fish tank for satisfy the oxygen requirements depends on the oxygen consumption of the fish, the oxygen concentration in the inlet water and the lowest acceptable concentration in the outlet water (Lekang, 2007). Hence effective hydraulic load rate (HLR) can be employed to achieve optimal growth for the fish and plants. Correlation of water flow rates and hydraulic loading rate with production in an aquaponic system was identified by (Hussain et al., 2015 and Nuwansi, et al. 2016) with using different fish and plant species, tested with different hydroponic systems.

(Hussain et al. 2015) investigated the effect of flow rate on the growth performance of the koi carp fingerlings and spinach and to analyze the effect of flow rate on water quality and nutrient removal in the aquaponic system. Kafr El-Sheikh governorate suffers at present time from a great lack of water, so it has become necessary to search for unconventional ways to save water in order to increase the vertical expansion of the plant production and the production of fish. So, the present study aimed to determine the optimum hydraulic loading rate for efficient working of the constructed wetland. Subsequently, study the effects of that hydraulic load on fish (Nile Tilapia) growth rate.

\section{MATERIALS AND METHODS}

The experiments were carried out during two seasons (May and June) 2015 and 2016. The experimental setup was installed in Faculty of Agriculture fish farm, Kafrelsheikh University, Kafr El-Sheikh 
Governorate, Egypt $\left(31^{\circ} 06^{\prime} \mathrm{N}-30^{\circ} 56^{\prime} \mathrm{E}\right)$. The experiment was carried out at two stages as follows:

\subsection{First stage:}

Constructed wetlands used in this stage of the study were subsurface-flow root zone systems with rice plants and horizontal effluent soil percolation. The cell dimensions of constructed wetland were $2 \times 0.5 \times 0.75 \mathrm{~m}$ (length $\times$ width $\times$ height). Wetland cell was filled with three layers of gravel, the bottom layer coarse gravel $(\phi 30-50 \mathrm{~mm})$ with height $0.3 \mathrm{~m}$, the middle layer fine gravel $(\phi 10-20 \mathrm{~mm})$ with height $0.2 \mathrm{~m}$ and the upper layer (soil) with height $0.05 \mathrm{~m}$. Wetland cell was cultured with rice and provided with two openings gate for water inlet and water outlet (drainage) (Fig. 1). The experimental design consisted of three treatments (Table 1).

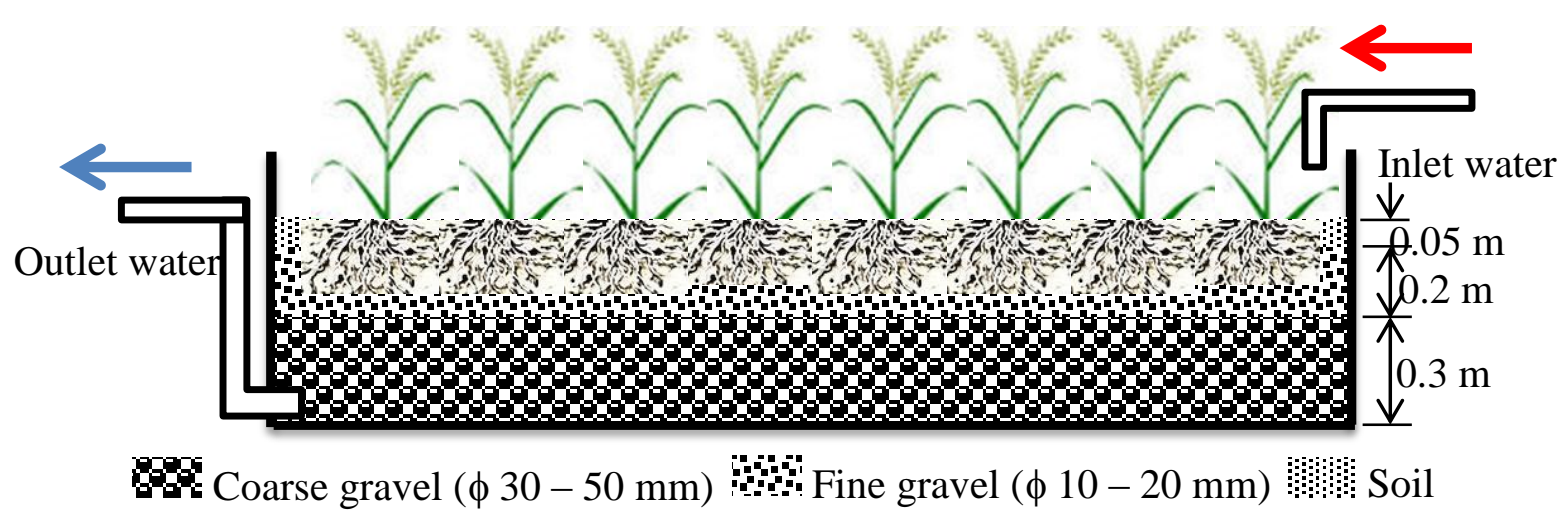

Fig. 1.Schematic diagram of the constructed wetland

Table 1: Water flow rate and hydraulic loading rate in different treatments of the experiments.

\begin{tabular}{|l|c|c|c|}
\hline Treatment & $\mathrm{T} 1$ & $\mathrm{~T} 2$ & $\mathrm{~T} 3$ \\
\hline Water flowrate, $1 . \mathrm{h}^{-1}$ & 200 & 400 & 800 \\
\hline Water flow rate $, \mathrm{Q},\left(\mathrm{m}^{3} \mathrm{~h}^{-1}\right)$ & 0.2 & 0.4 & 0.8 \\
\hline Hydraulic loading rate, HLR, $\left(\mathrm{m} \mathrm{day}^{-1}\right)$ & 4.8 & 9.6 & 19.2 \\
\hline
\end{tabular}


Hydraulic loading rate (HLR) of the system is calculated by dividing the flow rate of water, $\mathrm{Q}\left(\mathrm{m}^{3} \mathrm{day}^{-1}\right)$ through the system by the surface area of the constructed wetland, A ( $\left.\mathrm{m}^{2}\right)$ (Endut et al., 2010):

$$
H L R\left(m^{3} \text { day }^{-1}\right)=\frac{Q}{A}
$$

Differences $(\Delta p)$ between inflow and outflow concentrations were calculated for each parameter as well as each pair of simultaneous samples. The relative treatment efficiency $(\% \Delta)$ was calculated for each parameter as:

$$
\% \Delta=\left(\Delta p C_{i n}^{-1}\right) \cdot 100
$$

Where: $\Delta p=$ (inflow-outflow) concentration in $\mathrm{mgL}^{-1}$ and

$$
C_{\text {in }}=\text { inflow concentration in } \mathrm{mgL}^{-1} \text {. }
$$

The related area loading rates (AL in $\mathrm{g} \mathrm{m}^{-2} \mathrm{day}^{-1}$ ) and area removals (AR in $\mathrm{gm}^{-2} \mathrm{day}^{-1}$ ) of the wetland area applied were calculated as:

$$
\mathrm{AL}=\mathrm{C}_{\text {in }} \cdot \mathrm{HLR} \quad ; \quad \mathrm{AR}=\Delta \mathrm{p} \cdot \mathrm{HLR}
$$

For the nitrogen, biological oxygen demand $\left(\mathrm{BOD}_{5}\right)$ and dissolved oxygen (DO) budgeting the following formulae after Tchobanoglous et al. (2003) were used. The particulate nitrogen (PN) with in the system was calculated as:

$$
\mathrm{PN}=\mathrm{TN}-\left(\mathrm{TAN}+\mathrm{NO}_{2}-\mathrm{N}+\mathrm{NO}_{3}-\mathrm{N}\right) \ldots \ldots \ldots \ldots \ldots
$$

Where: $\mathrm{NO}_{2}-\mathrm{N}$ and $\mathrm{NO}_{3}-\mathrm{N}$ are nitrite and nitrate concentrations respectively.

It is supposed that theoretically all PN is available for nitrification, as the PN source are mainly undigested protein residuals derived from fish feed. Thus the availability of PN for nitrification is dependent on the oxygen amount within the wetland and will decrease with decreasing oxygen saturation, especially at low and very low values. Due to the high nitrogen mobility within the wetland from different storage forms (Kadlec et al., 2005) it can be assumed that at about $40 \%$ DO saturation, $100 \%$ of PN can be nitrified. At DO saturations below $40 \%$ in the wetland outflow, the amount of $\mathrm{PN}$ available for nitrification $\left(n_{\mathrm{PN}}\right)$ is calculated as:

$$
n_{P N}=\left(\frac{D O \%}{40 \%}\right) \cdot \Delta p(P N)
$$

Thus the total nitrification $(n)$ within the wetland cells is calculated:

$$
n=\Delta p(T A N)+n P N
$$


A part of the nitrified TAN and $\mathrm{PN}$ is released as $\mathrm{NO}_{2}-\mathrm{N}$ and $\mathrm{NO}_{3}-\mathrm{N}$ through the effluent out of the system, the remaining amount is denitrified. The amount of denitrification $(\mathrm{d} n)$ is calculate as:

$$
d n=n-\left(\Delta p\left(\mathrm{NO}_{2}-\mathrm{N}\right)+\Delta p\left(\mathrm{NO}_{3}-\mathrm{N}\right)\right)
$$

Per milligram of nitrogen denitrified, about $3.5 \mathrm{mg}$ of $\mathrm{BOD}_{5}$ is consumed as electron donor (Tchobanoglous et al., 2003; Van Rijin et al., 2006). Thus the theoretical DO consumption $\left(\mathrm{DO}_{\text {con. }}, \mathrm{mgl}^{-1}\right)$ was calculated as:

$$
D O_{\text {con. }}=\Delta p\left(B O D_{5}\right)-3.5 d n+4.25 n
$$

\subsection{Second stage:}

Fish pond wall was built from brick and had thickness of $26 \mathrm{~cm}$. The internal dimensions of the fish pond are $4 \times 1 \times 1 \mathrm{~m}$ (length $\times$ width $\times$ height). The air compressor capacity of 100 watts at a rate of air $1101 / \mathrm{min}$ was used for fish pond aeration. The fish pond was loaded with 120 fish. The average weight was $50.3 \mathrm{~g} / \mathrm{fish}$. The fish were fed by hand a commercial feed (crude protein, $27 \%$; crude lipid $5.06 \%$; crude fiber $5.08 \%$; total energy $4000 \mathrm{kcal} / \mathrm{kg}$ ) for 60 days. The diet was offered twice a day at 10:00 $\mathrm{h}$ and 16:00 h. Daily feeding rates (\% BW/day) were determined based on recommendations of different researchers. Therefore, the daily rates were of $6 \% \mathrm{BW} /$ day for 30 days. Fish were weighed every 10 days intervals and feed intake was adjusted every 10 days also. Fish were weighed using an electronic balance (Shimadzu, EB-620SU \pm 0.01 g sensitivity). The data collected every ten days and the growth rates were measured in terms of specific growth rate (SGR), weight gain during feed period (WGDFP), feed conversation efficiency (FCE) and condition factor (K) as the following (Fuentes-Silva et al. 2015):

$$
W G D F P=F W-I W
$$

Where:

$$
\begin{gathered}
\mathrm{FW}=\text { final weight, } \mathrm{g} . \\
D G R=\frac{F w-I W}{\text { experimental period } \times I W} \times 100
\end{gathered}
$$

Where:

$\mathrm{DGR}=$ daily growth rate, $\%$ 


$$
\begin{aligned}
S G R & =\left(\frac{\ln F W-\ln I W}{\text { time }(\text { day })}\right) * 100 \\
F C E & =\frac{\text { mass gained }(g)}{\text { total amount of feed consumed }(g)}
\end{aligned}
$$

\subsection{Statistical analysis:}

The data obtained from the experiments were subjected to one-way analysis of variance (ANOVA) using SPSS program to test the effect of the inflow and outflow nutrient concentration, removal efficiencies and treatment efficiencies at different hydraulic.

\section{RESULTS AND DISCUSSION}

\subsection{Water quality of inlet and outlet constructed wetland:}

Water quality parameters deviated with the flow rate in the present experiment (Table 2). Water temperature failed to show any significant variation throughout the experimental time for the values of control and hydraulic loading rates treatments. Water temperature is one amongst the necessary factors liable for optimum fish growth, plant growth, and performance of nitrifying bacterium in biofilter. Within the present study, water temperature was ranged between 21 and $24{ }^{\circ} \mathrm{C}$ that is appropriate for fish culture. All hydraulic loading rates treatments did not show any significant effect on water electrical conductivity which was found in desirable limits for fish as well as fish growth and constructed wetland functioning.

The water $\mathrm{pH}$ concentration throughout the study amount varied among a variety of $7.7-7.8$, with no marked variation among the treatments at time of sampling.

Hydraulic loading rate $\left(19.2 \mathrm{~m} \mathrm{day}^{-1}\right)$ showed significantly lower dissolved oxygen (DO) content than control and other hydraulic loading rates (4.8 and $9.6 \mathrm{~m} \mathrm{day}^{-1}$ ). DO levels in the water showed relative decrease with increasing hydraulic loading rates. DO was $4.11,3.32$ and $2.15 \mathrm{mg} \mathrm{l}^{-1}$ at hydraulic loading rates 4.8, 9.6 and $19.2 \mathrm{~m} \mathrm{day}^{-1}$ respectively.

The results indicated that the total ammonia nitrogen (TAN) concentration was significant variation among the hydraulic loading rates treatments and control. It was observed significantly highest in hydraulic 
loading rate $4.8 \mathrm{~m} \mathrm{day}^{-1}$. Total ammonia nitrogen (TAN) concentration increased with increasing hydraulic loading rates among treatments, whereas TAN values were $0.18,0.21$ and $0.23 \mathrm{mg} \mathrm{l}^{-1}$ at hydraulic loading rates 4.8, 9.6 and $19.2 \mathrm{~m}$ day $^{-1}$ respectively.

Significantly highest total nitrogen (TN) concentration was observed in control as compared to all hydraulic loading rates treatments. TN concentration decreased with increasing hydraulic loading rates among treatments, whereas $\mathrm{TN}$ values were $2.63,2.56$ and $2.46 \mathrm{mg} \mathrm{l}^{-1}$ at hydraulic loading rates 4.8, 9.6 and $19.2 \mathrm{~m} \mathrm{day}^{-1}$ respectively.

Nitrite $-\mathrm{N}\left(\mathrm{NO}_{2}-\mathrm{N}\right)$ of the water varied within narrow range and founded within optimum range for the fish as well as plant culture. Nitrate $-\mathrm{N}\left(\mathrm{NO}_{3}-\mathrm{N}\right)$ concentration at hydraulic loading rate $19.6 \mathrm{~m} \mathrm{day}^{-1}$ was higher with comparing other hydraulic loading rates and control. Nitrate $\mathrm{N}\left(\mathrm{NO}_{3}-\mathrm{N}\right)$ concentration values were $0.30,0.23$ and $32 \mathrm{mg} \mathrm{l}^{-1}$ at hydraulic loading rates $4.8 \mathrm{~m} 9.6$ and $19.2 \mathrm{~m} \mathrm{day}^{-1}$ respectively.

BOD concentration at hydraulic loading rate $4.8 \mathrm{~m} \mathrm{day}^{-1}$ was higher with comparing other hydraulic loading rates. BOD concentration values were 26, 23 and $25 \mathrm{mg} \mathrm{l}^{-1}$ at hydraulic loading rates $4.8 \mathrm{~m} 9.6$ and $19.2 \mathrm{~m} \mathrm{day}^{-1}$ respectively.

TSS concentration at hydraulic loading rate $19.2 \mathrm{~m} \mathrm{day}^{-1}$ was higher with comparing other hydraulic loading rates. TSS concentration values were 13,12 and $17 \mathrm{mg} \mathrm{l}^{-1}$ at hydraulic loading rates $4.8 \mathrm{~m} 9.6$ and $19.2 \mathrm{~m} \mathrm{day}^{-1}$ respectively.

\subsection{Hydraulic loading rate and nutrient removal:}

The results indicated that the nutrient to area loading (AL) and area retention (AR) increases with increasing the hydraulic load for most of the measured nutrient parameters (Table 3). The results indicated that the significant difference in AR between all hydraulic loading rates treatments $(4.8,9.6$ and $19.2 \mathrm{~m}$ day-1) for total nitrogen $(\mathrm{TN})$, total ammonia nitrogen (TAN) nitrate (NO3-N) and BOD. For TSS there was no significant difference in AR between the low and medium hydraulic loading rates (4.8 and $9.6 \mathrm{~m}$ day-1).

Nutrient removal efficiency in treatments varied in response to hydraulic loading rates. TN removal increased with increasing the hydraulic loading rates. The TN removal values were $7.1,9.5$ and $13.1 \%$ ate hydraulic 
Table 2: Water quality parameters observed during experimental period in different hydraulic loading rates.

\begin{tabular}{|c|c|c|c|c|}
\hline \multirow{2}{*}{ Parameter } & \multirow{2}{*}{ control } & \multicolumn{3}{|c|}{ Hydraulic loading rate, HLR, $\left(\mathrm{m} \mathrm{day}^{-1}\right)$} \\
\hline & & 4.8 & 9.6 & 19.2 \\
\hline Temperature, $\mathrm{C}^{\circ}$ & $24 \pm 2$ & $24 \pm 2$ & $24 \pm 2$ & $24 \pm 2$ \\
\hline Electrical conductivity, $\mu$ S.cm ${ }^{-1}$ & $0.579 \pm 0.012^{\mathrm{a}}$ & $0.585 \pm 0.010^{\mathrm{a}}$ & $0.585 \pm 0.013^{a}$ & $0.585 \pm 0.010^{\mathrm{a}}$ \\
\hline pH & $7.7 \pm 0.1^{\mathrm{a}}$ & $7.8 \pm 0.1^{\mathrm{a}}$ & $7.8 \pm 0.1^{\mathrm{a}}$ & $7.7 \pm 0.1^{\mathrm{a}}$ \\
\hline Dissolved oxygen, DO , mg. $\mathrm{I}^{-1}$ & $8.1 \pm 2^{\mathrm{a}}$ & $4.11 \pm 1^{b}$ & $3.32 \pm 1 b^{c}$ & $2.15 \pm 1^{\mathrm{c}}$ \\
\hline Total nitrogen, $\mathbf{T N}$, mg.l $^{-1}$ & $2.83 \pm 0.14^{\mathrm{a}}$ & $2.63 \pm 0.12^{b}$ & $2.56 \pm 0.11^{\text {bc }}$ & $2.46 \pm 0.11^{\mathrm{c}}$ \\
\hline Total ammonia nitrogen, TAN, mg. $\mathrm{l}^{-1}$ & $0.36 \pm 0.01^{\mathrm{a}}$ & $0.18 \pm 0.02^{b}$ & $0.21 \pm 0.01^{\text {bc }}$ & $0.23 \pm 0.01^{\mathrm{c}}$ \\
\hline Nitrite, $\mathrm{NO}_{2}-\mathrm{N}$, mg.l $^{-1}$ & $0.04 \pm 0.002^{a}$ & $0.04 \pm 0.002^{a}$ & $0.03 \pm 0.002^{\mathrm{a}}$ & $0.041 \pm 0.002^{a}$ \\
\hline Nitrate, $\mathrm{NO}_{3}-\mathrm{N}$, mg.l $^{-1}$ & $0.26 \pm 0.02^{\mathrm{a}}$ & $0.30 \pm 0.02^{b}$ & $0.23 \pm 0.02^{\mathrm{c}}$ & $0.32 \pm 0.02^{b}$ \\
\hline BOD, mg.l m $^{-1}$ & $31 \pm 3^{a}$ & $28.5 \pm 2^{b}$ & $27 \pm 2^{c}$ & $28 \pm 2^{\mathrm{bc}}$ \\
\hline TSS, mg.I ${ }^{-1}$ & $27 \pm 8^{\mathrm{a}}$ & $13 \pm 5^{b}$ & $12 \pm 7^{b}$ & $17 \pm 4^{\mathrm{c}}$ \\
\hline
\end{tabular}

Table 3: Area loading (AL), area retention (AR) $\left(\mathrm{g} \mathrm{m}^{-2} \mathrm{day}^{-1}\right)$ and the percentage of water parameters removed of the constructed wetland at different hydraulic loading rate.

\begin{tabular}{|c|c|c|c|c|c|c|c|c|c|}
\hline \multirow{3}{*}{$\begin{array}{c}\text { Water } \\
\text { parameter }\end{array}$} & \multicolumn{9}{|c|}{ Hydraulic Loading Rate, $4.8 \mathrm{~m} \mathrm{day}^{-1}$} \\
\hline & \multicolumn{3}{|c|}{$4.8 \mathrm{~m} \mathrm{day}^{-1}$} & \multicolumn{3}{|c|}{$9.6 \mathrm{~m} \mathrm{day}^{-1}$} & \multicolumn{3}{|c|}{$19.2 \mathrm{~m} \mathrm{day}^{-1}$} \\
\hline & $\mathbf{A L}$ & $\mathbf{A R}$ & $\underset{\%}{\text { Removed, }}$ & $\mathbf{A L}$ & $\mathbf{A R}$ & $\underset{\%}{\text { Removed, }}$ & $\mathbf{A L}$ & $\mathbf{A R}$ & $\underset{\%}{\text { Removed, }}$ \\
\hline DO & 38.9 & 19.2 & 49.3 & 77.8 & 45.9 & 59.0 & 155.5 & 114.2 & 73.5 \\
\hline $\mathbf{T N}$ & 13.6 & $1.0^{\mathrm{a}}$ & 7.1 & 27.2 & $2.6^{\mathrm{b}}$ & 9.5 & 54.3 & $7.1^{\mathrm{c}}$ & 13.1 \\
\hline TAN & 1.7 & $0.9^{\mathrm{a}}$ & 50.0 & 3.5 & $1.4^{\mathrm{b}}$ & 41.7 & 6.9 & $2.5^{\mathrm{c}}$ & 36.1 \\
\hline $\mathrm{NO}_{2}-\mathrm{N}$ & 0.2 & 0.0 & 0.0 & 0.4 & $0.1^{\mathrm{a}}$ & 25.0 & 0.8 & $-0.02^{b}$ & -2.5 \\
\hline $\mathrm{NO}_{3}-\mathrm{N}$ & 1.2 & $-0.2^{\mathrm{a}}$ & -15.4 & 2.5 & $0.3^{\mathrm{b}}$ & 11.5 & 5.0 & $-1.2 \mathrm{c}$ & -23.1 \\
\hline BOD & 148.8 & $12^{\mathrm{a}}$ & 8.1 & 297.6 & $38.4^{b}$ & 12.9 & 595.2 & $57.6^{c}$ & 9.7 \\
\hline TSS & 96.0 & $33.6^{\mathrm{a}}$ & 35.0 & 192.0 & $76.8^{\mathrm{a}}$ & 40.0 & 384.0 & $57.6^{b}$ & 15.0 \\
\hline
\end{tabular}


loading rates 4.8, 9.6 and $19.2 \mathrm{~m}^{-1} \mathrm{day}^{-1}$ respectively. While, the TAN was decreased with increasing the hydraulic loading rates. The TAN values were 50, 41.7 and $36.1 \%$ ate hydraulic loading rates 4.8, 9.6 and $19.2 \mathrm{~m}$ day-1 respectively. For NO2-N, the area retention was zero at low hydraulic loading rate $(4.8 \mathrm{~m}$ day-1), however the NO2-N removal recorded zero too. There was significant difference in NO2-N removal (25 and $-2.5 \%$ ) between the medium and high hydraulic loading rates (9.6 and $19.2 \mathrm{~m}$ day-1 respectively). There was significant difference in NO3-N removal $(-15.4,11.5$ and $-23.1 \%)$ between all hydraulic loading rates treatments $\left(4.8,9.6\right.$ and $19.2 \mathrm{~m} \mathrm{day}^{-1}$ respectively). The BOD removal values were $8.1,12.9$ and $9.7 \%$ at hydraulic loading rate 4.8, 9.6 and $19.2 \mathrm{~m} \mathrm{day}^{-1}$ respectively. the TSS removal increased with increasing hydraulic loading rates (Fig. 2).

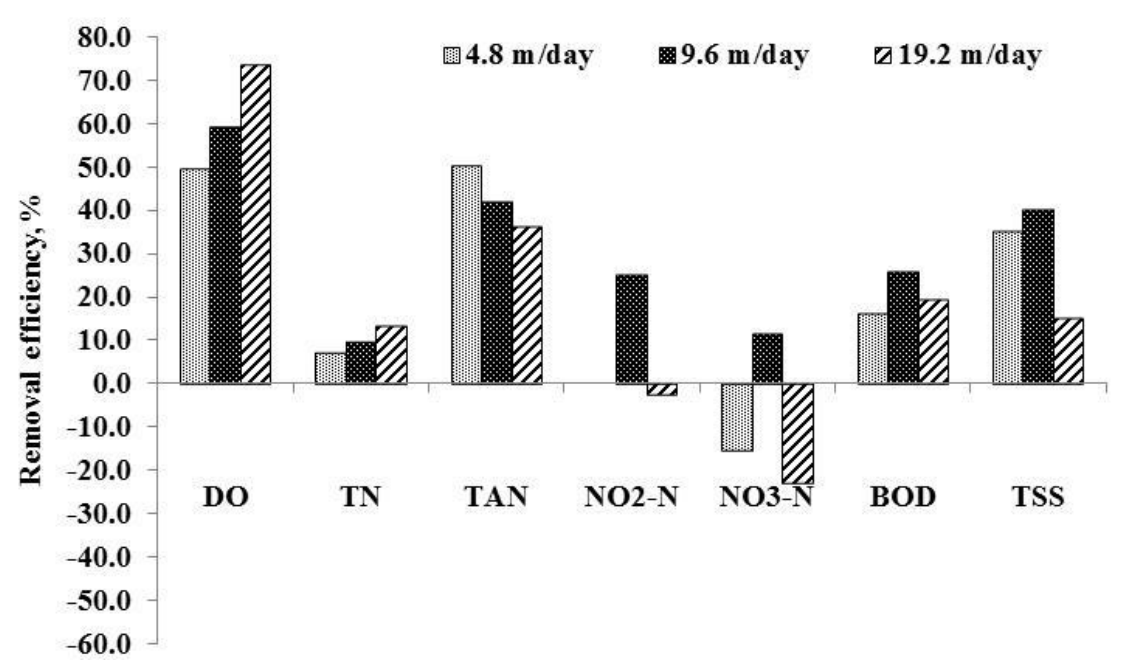

Fig. 2: Wetland nutrient removal efficiency at different hydraulic loading rates.

The particulate nitrogen (PN) in the wetland increased with decreasing hydraulic loading rate. The (PN) values were $2.11,2.09$ and $1.87 \mathrm{mgl}^{-1}$ at hydraulic loading rate 4.8, 9.6 and $19.2 \mathrm{~m} \mathrm{day}^{-1}$ respectively (Table 4). The values of nitrification (n) were $0.25,0.23$ and $0.32 \mathrm{mg} \mathrm{l}^{-1}$, while the 
values of denitrification $(\mathrm{dn})$ were $0.29,0.19$ and $0.38 \mathrm{mg} \mathrm{l}^{-1}$ at the hydraulic loading rate $4.8,9.6$ and $19.2 \mathrm{~m} \mathrm{day}^{-1}$ respectively. The theoretical dissolved oxygen consumption $\left(\mathrm{DO}_{\mathrm{con}}\right)$ of $2.6,4.3$ and $3 \mathrm{mg} \mathrm{l}^{-}$ ${ }^{1}$, representing $65 \%, 90 \%$ and $50 \%$ of the measured DO loss throughout the wetland at hydraulic loading rate 4.8, 9.6 and $19.2 \mathrm{~m} \mathrm{day}^{-1}$ respectively. The total ammonia removal rate (TAN) $(0.86,1.44$ and 2.5 $\left.\mathrm{gm}^{-2} \mathrm{day}^{-1}\right)$ increased with increasing hydraulic loading rate $(4.8,9.6$ and $19.2 \mathrm{~m} \mathrm{day}^{-1}$ ).

Table 4: The calculation of DO consumption $\left(\mathrm{DO}_{\text {con, }} \mathrm{mg} \mathrm{l}^{-1}\right)$ required for nitrogen denitrified and the TAN removal rate, $\mathrm{g} \mathrm{m}^{-2} \mathrm{day}^{-1}$.

\begin{tabular}{|c|c|c|c|}
\hline \multirow{2}{*}{ Water parameter } & \multicolumn{3}{|c|}{ Hydraulic loading rates, $\mathrm{m}_{\text {day }}{ }^{-1}$} \\
\hline & 4.8 & 9.6 & 19.2 \\
\hline $\mathrm{PN}, \mathrm{mg} \mathrm{l}^{-1}$ & 2.11 & 2.09 & 1.87 \\
\hline$\Delta \mathrm{p} \mathrm{PN}, \mathrm{mg} \mathrm{l}^{-1}$ & 0.06 & 0.08 & 0.30 \\
\hline $\mathrm{DO}, \%$ & 0.49 & 0.40 & 0.26 \\
\hline $\mathrm{n}_{\mathrm{PN}}, \mathrm{mg} \mathrm{l}^{-1}$ & 0.07 & 0.08 & 0.19 \\
\hline$\Delta \mathrm{p}$ TAN, $\mathrm{mg}^{-1}$ & 0.18 & 0.15 & 0.13 \\
\hline $\mathrm{n}, \mathrm{mg} \mathrm{l}^{-1}$ & 0.25 & 0.23 & 0.32 \\
\hline $\mathrm{dn}, \mathrm{mg} \mathrm{l}^{-1}$ & 0.29 & 0.19 & 0.38 \\
\hline$\Delta \mathrm{p} \mathrm{BOD}, \mathrm{mg}^{-1}$ & 2.5 & 4 & 3 \\
\hline $\mathrm{DO}_{\text {con }}, \mathrm{mg} \mathrm{l}^{-1}$ & 2.6 & 4.3 & 3.0 \\
\hline$\Delta \mathrm{p} \mathrm{DO}, \mathrm{mg} \mathrm{l}^{-1}$ & 3.99 & 4.78 & 5.95 \\
\hline$\left(\mathrm{DO}_{\mathrm{con}} / \Delta \mathrm{p} \mathrm{DO}\right) 100, \%$ & 65 & 90 & 50 \\
\hline TAN removal rate, $\mathrm{g} \mathrm{m}^{-2}$ day $^{-1}$ & 0.86 & 1.44 & 2.50 \\
\hline
\end{tabular}

\subsection{Fish growth parameters:}

The results indicated that, no noticeable difference between fish growth parameters observed under hydraulic loading rate $9.6 \mathrm{~m} \mathrm{day}^{-1}$ with control treatment (Table 5). Weight gain during feeding period values were 33.62 and $33.78 \mathrm{~g}$ at hydraulic loading rate $9.6 \mathrm{~m} \mathrm{day}^{-1}$ and control treatment respectively. While, the Specific growth rate and Feed conversion efficiency hade the same values in all treatments. 
Table 5: Comparing between fish growth parameters observed under hydraulic loading rate $9.6 \mathrm{~m} \mathrm{day}^{-1}$ with control treatment.

\begin{tabular}{|l|c|c|}
\hline \hline Parameters & $\begin{array}{c}\text { Hydraulic loading } \\
\text { rate } 9.6 \mathrm{~m} \mathrm{day}^{-1}\end{array}$ & Control \\
\hline Initial weight(IW), $\mathrm{g}$ & 50.3 & 50.3 \\
\hline Final weight (FW), g & 83.84 & 8391 \\
\hline Weight gain during feeding period (WGDFP), g & 33.54 & 33.61 \\
\hline Daily growth rate (DGR), \% & 1.11 & 1.11 \\
\hline Specific growth rate (SGR), \% & 0.85 & 0.85 \\
\hline Feed conversion efficiency (FCE), \% & 79.93 & 80.1 \\
\hline
\end{tabular}

\section{CONCLUSION}

In conclusion, the present results revealed that nutrient removal efficiency in treatments varied in response to hydraulic loading rates. TN removal increased with increasing the hydraulic loading rates. The results indicated that, no noticeable difference between fish growth parameters observed under hydraulic loading rate $9.6 \mathrm{~m} \mathrm{day}^{-1}$ with control treatment.

\section{REFERENCES}

Bergheim, A. and Brinker, A. (2003). Effluent treatment for flow-through systems and European environmental regulations. Aquacul. Eng. 27, 61-77.

Endut, A., Jusoh, A., Ali, N.,Wan Nik,W.B., Hassan, A. (2010). A study on the optimal hydraulic loading rate and plant ratios in recirculation aquaponic system. Bioresour. Technol. 101, 15111517.

Fuentes-Silva C., G.M. Soto-Zarazua, I. Torres-Pacheco, R.G. GuevaraGonzález, J.F. García-Trejo, A. Flores-Rangel, J. Caballero-Pérez and A. Cruz-Hernández, 2015. Influence of Extended Photoperiod on All Male Nile Tilapia (Oreochromis niloticus) Production, Differential Gene Expression and Growth Rate. INTERNATIONAL JOURNAL OF AGRICULTURE \& BIOLOGY. ISSN Print: 1560-8530; ISSN Online: 1814-9596.

Hummer, D. A. and Bastian, R. K. (1989). Wetlands ecosystems: natural water purifiers? In: Hammer, D. A. (Ed), Constructed wetlands for wastewater treatment: Municipal, Industrial and Agricultural, Lewis Publishers, Chelsea, pp. 5-19.

Hussain T.; A. K. Verma; V. K. Tiwari; C. Prakash ; G. Rathore; A. P. Shete; N. Saharan (2015). Effect of water flow rates on growth of 
Cyprinus carpio var. koi (Cyprinus carpio L., 1758) and spinach plant in aquaponic system. Aquacult Int. 23:369-384.

Kadlec, R.H., Tanner, C.C., Hally, V.M., Gibbs, M.M., 2005. Nitrogen spiraling in subsurface-flow constructed wetlands: implications for treatment response. Ecol. Eng. 25, 365-381.

Lekang, O.I. (2007). Aquaculture Engineering. Blackwell Publishing Ltd., Oxford, UK, p. 352.

Nuwansi, K. K. T.; A. K. Verma; C. Prakash ; V. K. Tiwari; M. H. Chandrakant; A. P. Shete; G. P. W. A. Prabhath (2016). Effect of water flow rate on polyculture of koi carp (Cyprinus carpio var. koi) and goldfish (Carassius auratus) with water spinach (Ipomoea aquatica) in recirculating aquaponic system. Aquacult Int. 24:385393.

Rennert, B., 1994. Water pollution by a land-based trout farm. J. Appl. Ichthyol. 10, 373- 378.

Schobert, G., Appel, E., Hofmann, H., Negele, D., Paravicini, R., Reiter, R., Sanzin, W.-D., Schadl,G., Weiكbrodt, L., Wondrak, P.(2001), Empfehlungen für den Bau und Betrieb von Fischteichen. In: Bayerisches Landesamt für Wasserwirtschaft, München (Ed). Materialein 99, 42 pp.

Shpigel M.; D. Ben-Ezra; L. Shauli; M. Sagi; Y. Ventura; T. Samocha and J. J. Lee (2013). Constructed wetland with salicornia as a biofilter for mariculture effluents. Aquaculture, 52-63.

Sindilariu, P. D., Wolter, C., Reiter, R., 2008. Constructed wetlands as a treatment method for effluents from intensive trout farms. Aquaculture 277, 179-184.

Sindilariu, P. D.; Alexander B.; Reinhard R. (2009). Factors influencing the efficiency of constructed wetlands used for the treatment of intensive trout farm effluent. Ecological Engineering 3 5: 711-722.

Sindilariu, P.-D.(2007). Reduction in effluent nutrient loads from flowthrough facilities for trout production: a review. Aquacult. Res. 38, 1005-1036.

Tchobanoglous, G., Burton, F.L., Stensel, H.D. (2003). Wastewater Engineering: Treatment and Reuse, 4th ed. McGraw-Hill Inc., New York, 1334 pp. 
Van Rijin, J.; Tal, Y. and Shreier. (2006). Denitrification in recirculating systems: theory and applications. Aquacultural Engineering, 34, 364-376.

\section{الملخص العربي \\ كفاءة استخدام الاراضي الرطبة في ازالة المخلفات ونمو اسماك البلطي النيلي

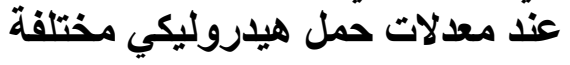

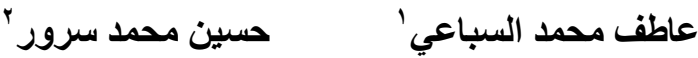

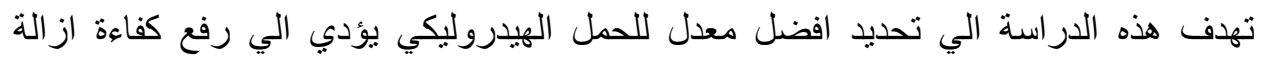

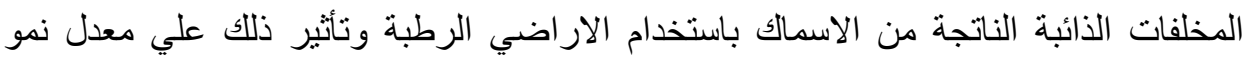

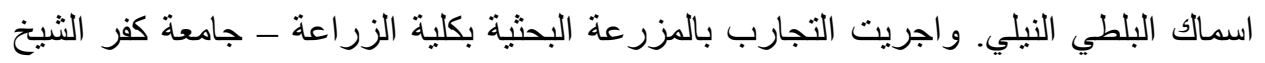

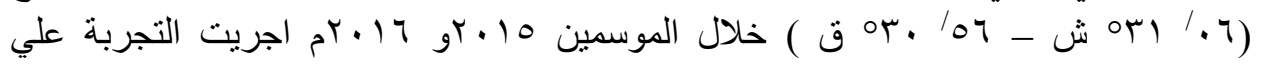

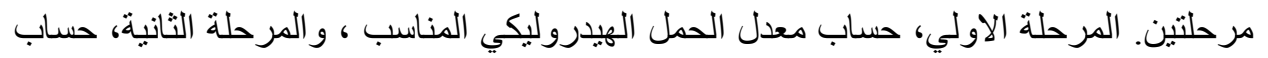

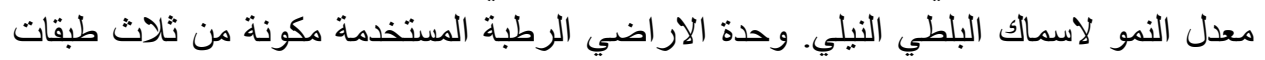

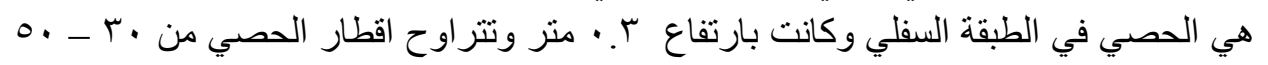

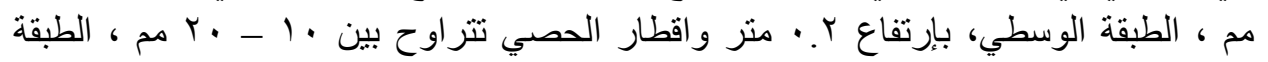

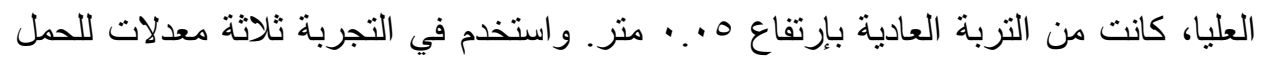

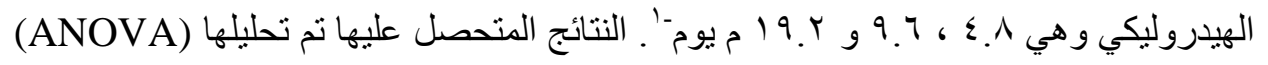

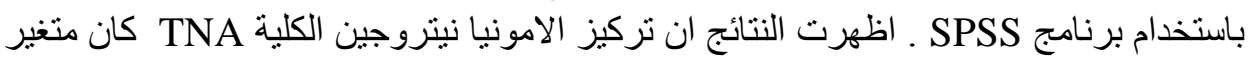

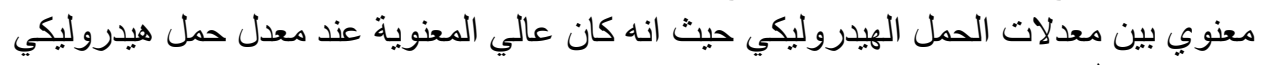

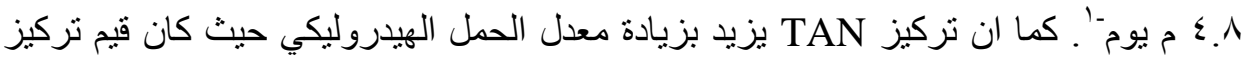

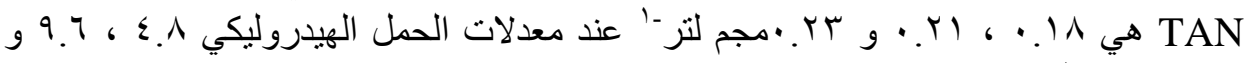

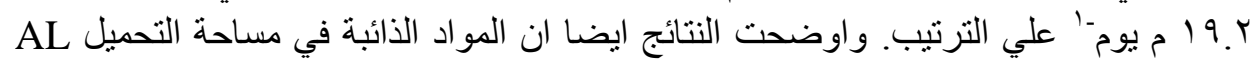

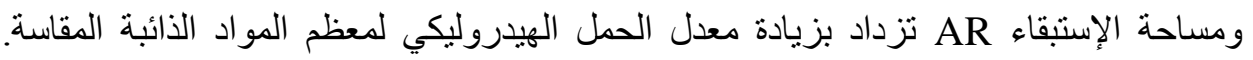

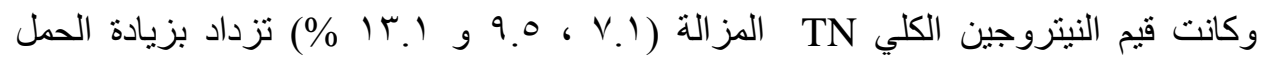

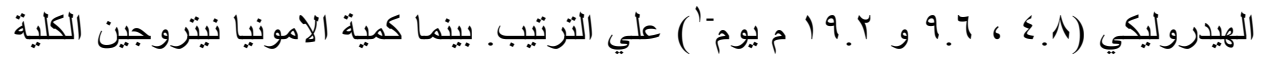

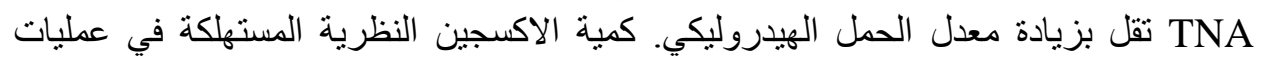

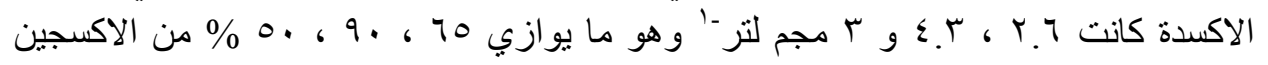

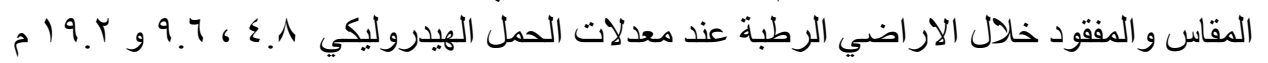

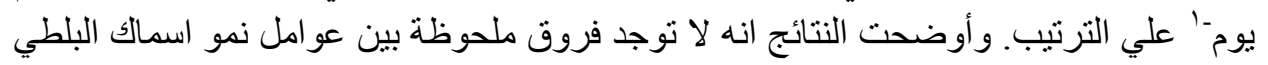

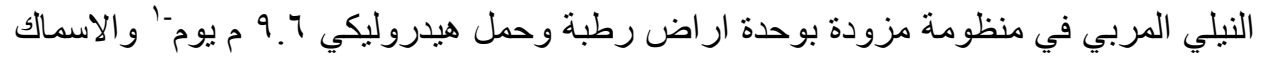
المرباه في نظام عادي.

'مدرس الهندسة الزراعية ـ قسم الهندسة الزراعية ـ كلية الزراعة ـ ـاعماعة كفر الثيخ.

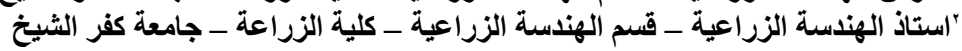

